\title{
Evaluation of Bacterial RNA Polymerase Inhibitors in a Staphylococcus aureus-Based Wound Infection Model in SKH1 Mice
}

Jörg Haupenthall ${ }^{1,}$, Yannik Kautz², Walid A. M. Elgaher ${ }^{1}$, Linda Pätzold², Teresa Röhrig1, Matthias W. Laschke ${ }^{3}$, Thomas Tschernig ${ }^{4}$, Anna K. H. Hirsch ${ }^{1,5}$, Vadim Molodtsove, ${ }^{6,7}$ Katsuhiko S. Murakami ${ }^{6}$, Rolf W. Hartmann ${ }^{1,5}$ and Markus Bischoff ${ }^{2}$

${ }^{1}$ Department of Drug Design and Optimization, Helmholtz Institute for Pharmaceutical Research Saarland (HIPS) - Helmholtz Centre for Infection Research (HZI), Campus Building E8.1, 66123 Saarbrücken, Germany

2 Institute of Medical Microbiology and Hygiene, Saarland University, 66421 Homburg/Saar, Germany

3 Institute for Clinical \& Experimental Surgery, Saarland University, 66421 Homburg/Saar, Germany

4 Institute of Anatomy and Cell Biology, Saarland University, 66421 Homburg/Saar, Germany

${ }^{5}$ Department of Pharmacy, Saarland University, Campus Building E8.1, 66123 Saarbrücken, Germany

${ }^{6}$ Department of Biochemistry and Molecular Biology, The Center for RNA Molecular Biology, The Pennsylvania State University, University Park, PA 16802, USA

7 Current address: Waksman Institute and Department of Chemistry, Rutgers University, Piscataway NJ 08854, USA

*Corresponding author. E-mail: Joerg.Haupenthal@Helmholtz-HIPS.de 


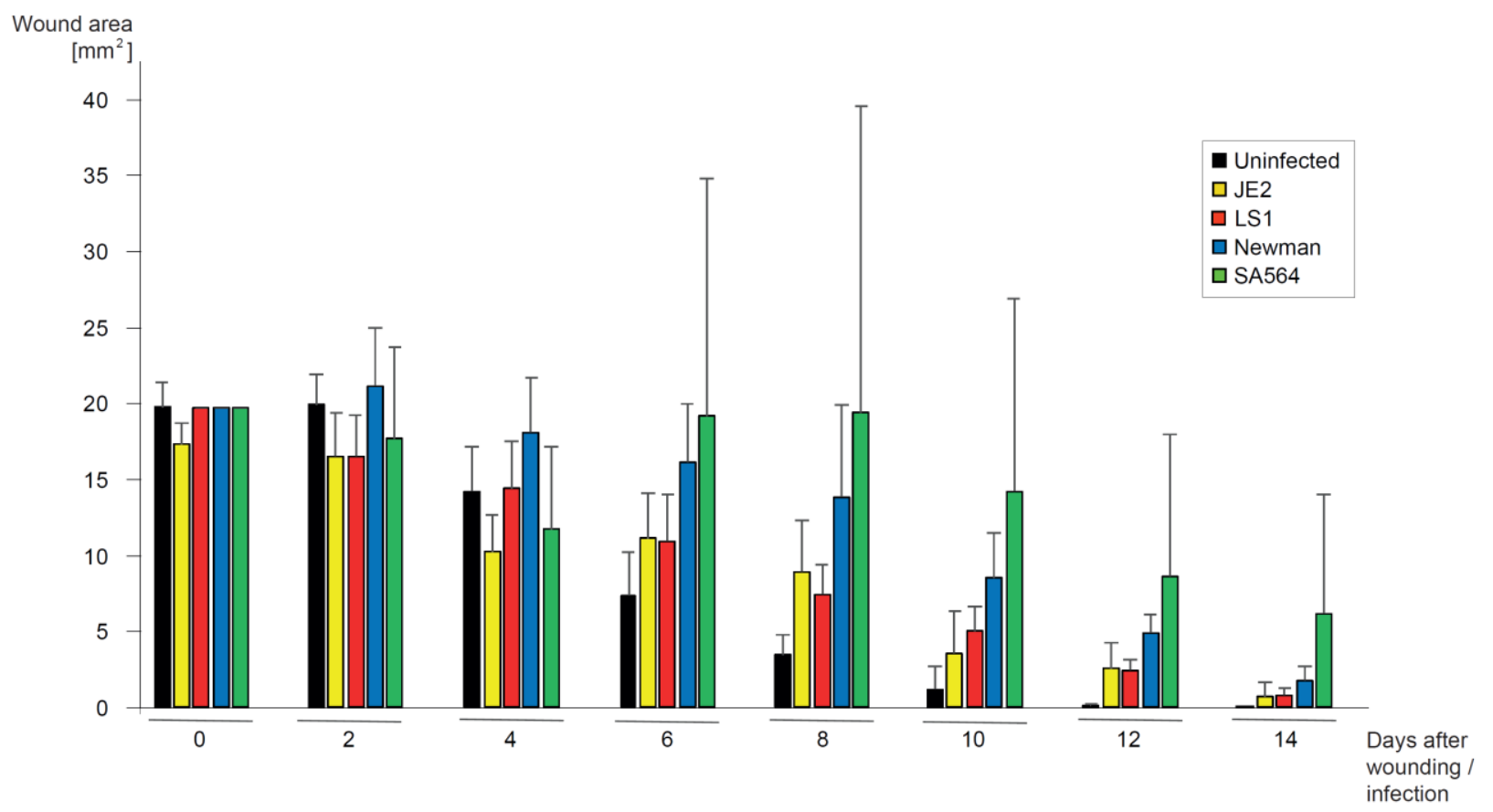

Figure S1: Influence of different $\mathbf{S}$. aureus strains on wound healing. SKH1 mice were wounded twice dorsally with a $5 \mathrm{~mm}$ (diameter) biopsy punch and subsequently infected with $10 \mu \mathrm{L}$ (OD 1.0) of either the S. aureus strain JE2, LS1, Newman or SA564. On day 0 and then every two days until day 14 , the wound sizes were determined and compared to uninfected wounds. At least eight wounds per group were examined. Based on the wound sizes measured and the standard deviations in these experiments we chose to perform the following experiments with the $S$. aureus Newman strain. 


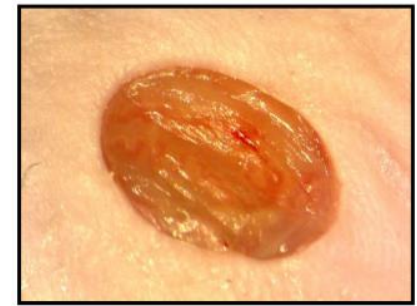

Uninfected

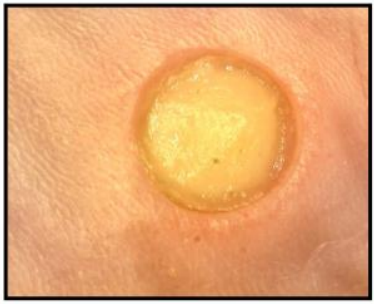

Infected

with $S$. aureus

Newman

Figure S2: Illustration of an uninfected punch wound (left image) and a punch wound infected with $S$. aureus Newman (right image). Pictures were taken $48 \mathrm{~h}$ after punch wound formation and (non-)infection.

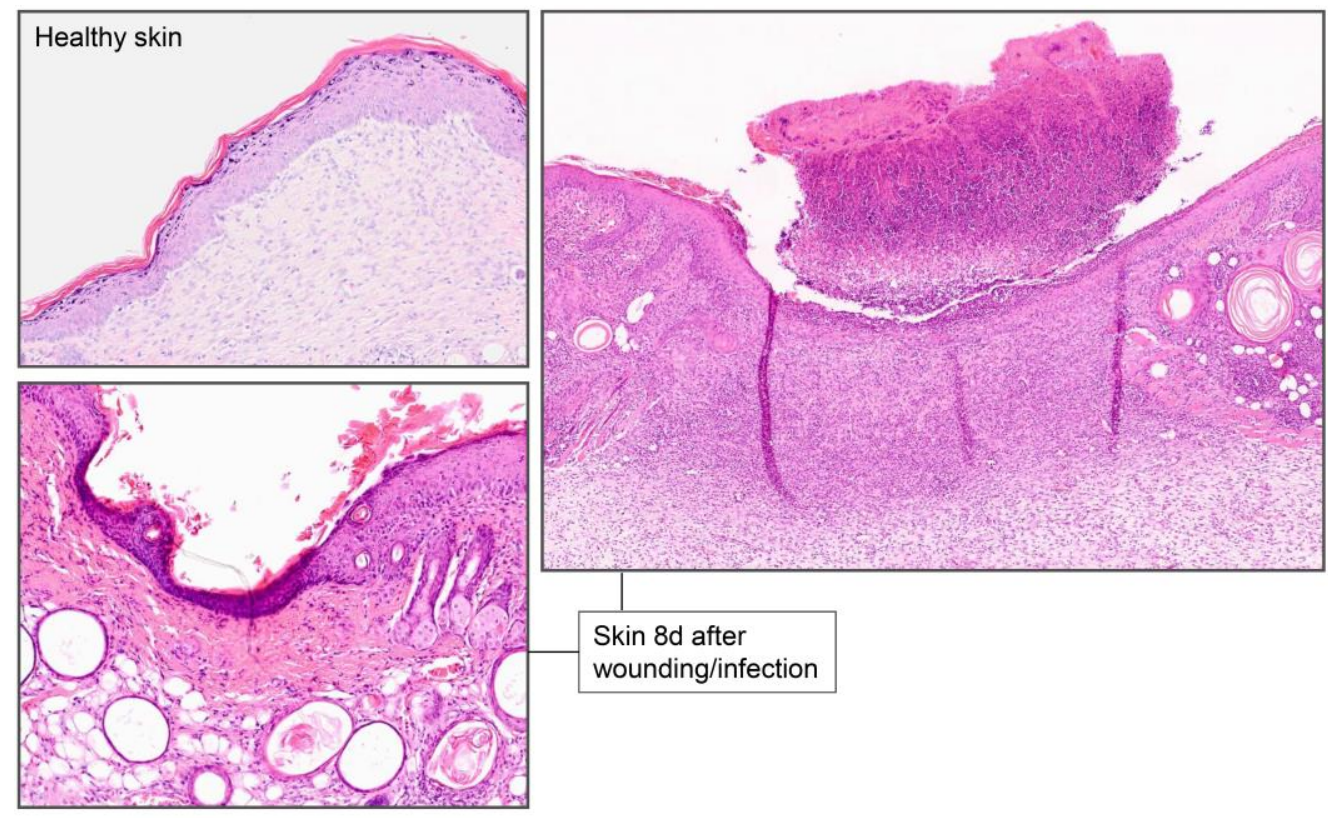

Figure S3: Haematoxylin and eosin (H\&E) staining of paraffin sections. Healthy (upper left) and wounded and infected (with $S$. aureus Newman) skin sections (lower left and right, respectively) are shown eight days after wounding/infection. 
Table S1: Biological evaluation of selected RNAP inhibitors. Our six most promising compounds with ureidothiophene-2/3-carboxylic acid core structure showed RNAP inhibition with $\mathrm{IC}_{50}$ values in the one to two digit $\mu \mathrm{M}$ range, as published previously ${ }^{1-3}$. This inhibition was accompanied by a high antibacterial potency against $S$. aureus Newman, a sufficient solubility in PBS (1\% DMSO) and a moderate to low cytotoxicity.

\begin{tabular}{|c|c|c|c|c|}
\hline & $\begin{array}{c}\text { MIC SA-N } \\
(\mu \mathrm{g} / \mathrm{mL})\end{array}$ & $\begin{array}{c}\text { RNAP } \\
\text { inhibition } \\
(\mathrm{IC} 50 \text { in } \mu \mathrm{M})\end{array}$ & $\begin{array}{c}\text { Cytotoxicity } \\
\text { in HEK293 } / \\
\text { NHDF cells } \\
\left(I C_{50} \text { in } \mu \mathrm{M}\right)\end{array}$ & $\begin{array}{c}\text { Solubility } \\
\text { in PBS } \\
(\mu \mathrm{M})\end{array}$ \\
\hline & 4 & 14 & $61 />100$ & 100 \\
\hline
\end{tabular}


Table S2: Data collection and refinement statistics of the RNAP-compound 1 complex. Data sets were collected at MacCHESS F1 line, Ithaca, NY. *Highest resolution shells are shown in parentheses.

\begin{tabular}{ll}
\hline PDB ID & $6 \mathrm{VJS}$ \\
\hline Data collection & \\
Space group & $\mathrm{P} 2{ }_{1} 2{ }_{1}{ }_{1}$ \\
Cell dimensions & \\
$\quad$ a $(\AA)$ & 187.077 \\
$\quad b(\AA)$ & 205.501 \\
$\quad c(\AA)$ & 309.88 \\
Resolution $(\AA)$ & $50-4.0$ \\
Total reflections & 553,863 \\
Unique reflections & 99,376 \\
Redundancy & $5.6(5.2)$ \\
Completeness $(\%)$ & $99.44(96.49)$ \\
I/ $\sigma$ & $11.02(1.95)$ \\
Wilson B-factor & 157.43 \\
R-merge & $0.1056(0.8696)$ \\
R-meas & $0.1167(0.9644)$ \\
CC ${ }^{1 / 2}$ & $0.998(0.728)$ \\
CC & $0.999(0.918)$ \\
& \\
Refinement &
\end{tabular}




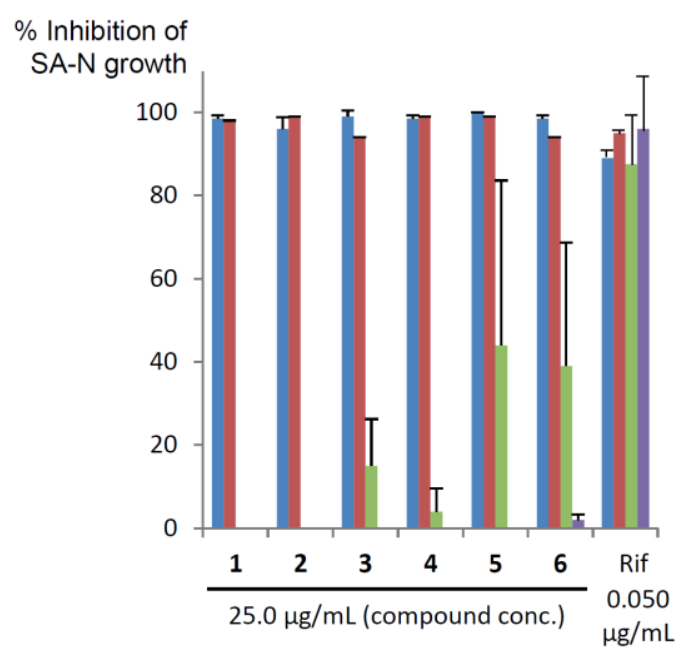

Figure S4: Concentration-dependent influence of bovine serum albumin (BSA) on the antibacterial activity of compounds 1-6 and rifampicin (Rif). Increasing concentrations of BSA (0 to $20 \mathrm{mg} / \mathrm{mL}$ ) were incubated together with (A) $25 \mu \mathrm{g} / \mathrm{mL}$ of compounds $1-6$ or $0.05 \mu \mathrm{g} / \mathrm{mL}$ of Rif and in parallel (B) together with 12.5 $\mu \mathrm{g} / \mathrm{mL}$ of compounds $1-6$ or $0.025 \mu \mathrm{g} / \mathrm{mL}$ of Rif. 


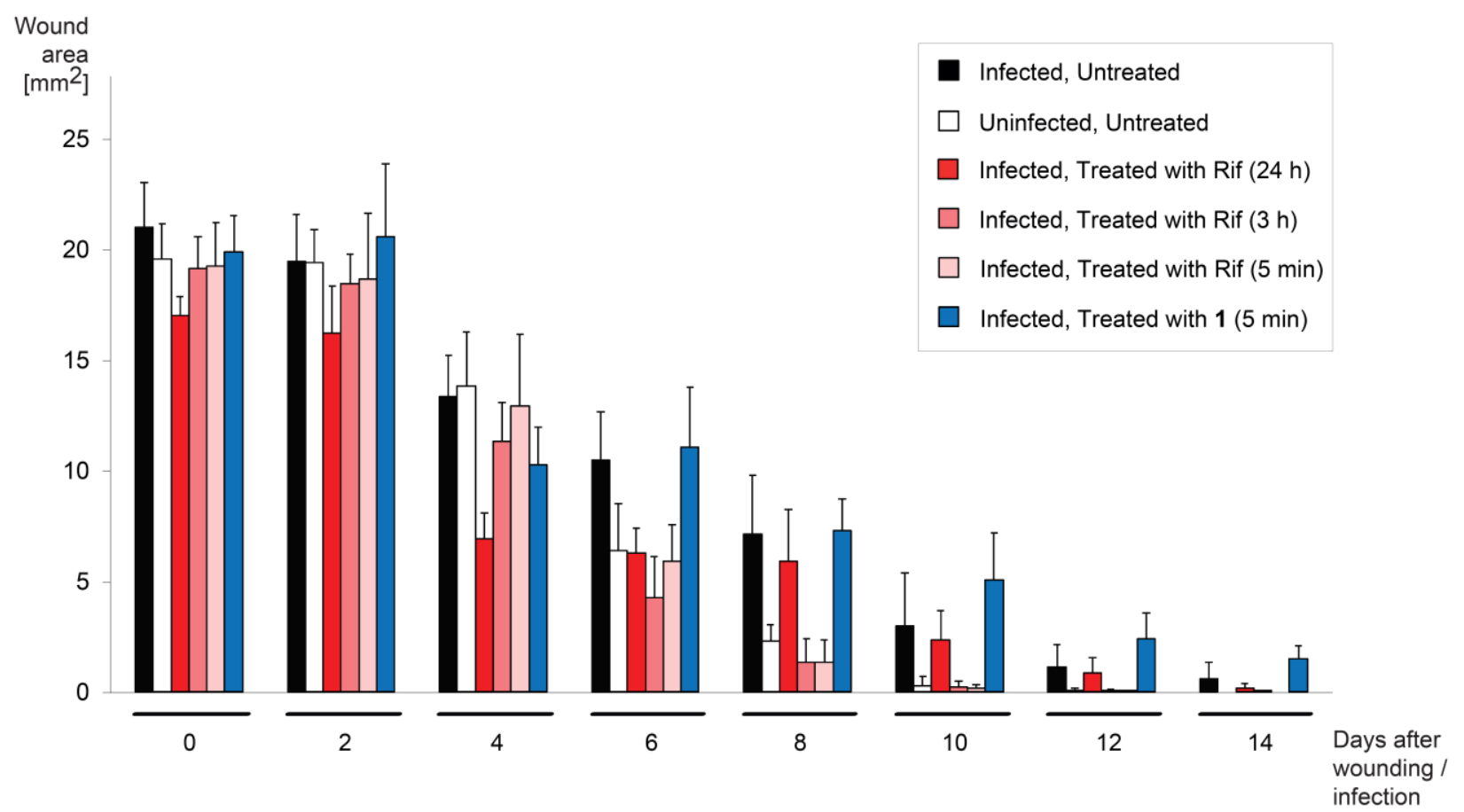

Figure S5: Development of wound size. The averaged wound areas (in $\mathrm{mm}^{2}$ ) are displayed every $2 \mathrm{~d}$ for the different treatment groups, between 0 and $14 \mathrm{~d}$ after wounding/infection. 
Table S3: Number of animals or wounds per experimental group.

\begin{tabular}{|c|c|c|c|}
\hline Referring to & Type of treatment & $\begin{array}{l}\text { Animals or } \\
\text { wounds }\end{array}$ & $\begin{array}{l}\text { Number of } \\
\text { animals/wounds }\end{array}$ \\
\hline Figure 1 & S. aureus OD 0.00 & Animals & 13 \\
\hline Figure 1 & S. aureus OD 0.01 & Animals & 6 \\
\hline Figure 1 & S. aureus OD 0.10 & Animals & 14 \\
\hline Figure 1 & S. aureus OD 1.00 & Animals & 10 \\
\hline Figure S1 & Uninfected & Wounds & 16 \\
\hline Figure S1 & S. aureus strain LS1 & Wounds & 8 \\
\hline Figure S1 & S. aureus strain Newman & Wounds & 8 \\
\hline Figure S1 & S. aureus strain SA564 & Wounds & 8 \\
\hline Figure S1 & S. aureus strain USA 300 JE2 & Wounds & 12 \\
\hline Figure 4 & S. aureus OD $0.10+$ PBS after $5 \mathrm{~min}$ and $48 \mathrm{~h}$ & Animals & 14 \\
\hline Figure 4 & PBS after 5 min and $48 \mathrm{~h}$ & Animals & 8 \\
\hline Figure 4 & S. aureus OD $0.10+$ Rif after $24 \mathrm{~h}$ and $48 \mathrm{~h}$ & Animals & 6 \\
\hline Figure 4 & S. aureus OD $0.10+$ Rif after $3 \mathrm{~h}$ and $48 \mathrm{~h}$ & Animals & 5 \\
\hline Figure 4 & S. aureus OD $0.10+$ Rif after 5 min and $48 \mathrm{~h}$ & Animals & 8 \\
\hline Figure 4 & S. aureus OD $0.10+$ Compound 1 after $5 \mathrm{~min}$ and $48 \mathrm{~h}$ & Animals & 4 \\
\hline Figures 5 and $\mathrm{S} 5$ & S. aureus OD $0.10+\mathrm{PBS}$ after $5 \mathrm{~min}$ and $48 \mathrm{~h}$ & Wounds & 8 \\
\hline Figures 5 and $\mathrm{S} 5$ & PBS after 5 min and $48 \mathrm{~h}$ & Wounds & 10 \\
\hline Figures 5 and $\mathrm{S} 5$ & S. aureus OD $0.10+$ Rif after $24 \mathrm{~h}$ and $48 \mathrm{~h}$ & Wounds & 12 \\
\hline Figures 5 and $\mathrm{S} 5$ & S. aureus OD $0.10+$ Rif after $3 \mathrm{~h}$ and $48 \mathrm{~h}$ & Wounds & 10 \\
\hline Figures 5 and $\mathrm{S} 5$ & S. aureus OD $0.10+$ Rif after 5 min and $48 \mathrm{~h}$ & Wounds & 8 \\
\hline Figures 5 and $\mathrm{S} 5$ & S. aureus OD $0.10+$ Compound 1 after $5 \mathrm{~min}$ and $48 \mathrm{~h}$ & Wounds & 4 \\
\hline Figure 6 & S. aureus OD $0.10+$ PBS after $5 \mathrm{~min}$ and $48 \mathrm{~h}$ & Wounds & 7 \\
\hline Figure 6 & PBS after 5 min and $48 \mathrm{~h}$ & Wounds & 14 \\
\hline Figure 6 & S. aureus OD $0.10+$ Rif after $24 \mathrm{~h}$ and $48 \mathrm{~h}$ & Wounds & 12 \\
\hline Figure 6 & S. aureus OD $0.10+$ Rif after $3 \mathrm{~h}$ and $48 \mathrm{~h}$ & Wounds & 10 \\
\hline Figure 6 & S. aureus OD $0.10+$ Rif after $5 \mathrm{~min}$ and $48 \mathrm{~h}$ & Wounds & 8 \\
\hline Figure 6 & S. aureus OD $0.10+$ Compound 1 after $5 \mathrm{~min}$ and $48 \mathrm{~h}$ & Wounds & 4 \\
\hline
\end{tabular}




\section{Materials and Methods}

\section{Origin, synthesis and characterization of RNAP inhibitors}

Rifampicin was purchased from Merck (Darmstadt, Germany). Starting materials and solvents were purchased from commercial suppliers, and used without further purification. Reaction progress was monitored using TLC silica gel $60 \mathrm{~F}_{254}$ aluminum sheets, and visualization was accomplished by UV at 254 $\mathrm{nm}$. Flash chromatography was performed using silica gel $60 \AA(40-63 \mu \mathrm{m})$. NMR spectra were recorded on a Bruker Avance Neo $500 \mathrm{MHz}$ with CryoProbe Prodigy system $\left({ }^{1} \mathrm{H}, 500 \mathrm{MHz} ;{ }^{13} \mathrm{C}, 126 \mathrm{MHz}\right)$ at $298 \mathrm{~K}$. Chemical shifts were recorded as $\delta$ values in ppm units by reference to the hydrogenated residues of deuterated solvent as internal standard $\left(\mathrm{CDCl}_{3}, \delta=7.27,77.00\right.$; DMSO-d $\left.\mathrm{d}_{6}, \delta=2.50,39.51\right)$. Splitting patterns describe apparent multiplicities and are designated as s (singlet), br s (broad singlet), $d$ (doublet), $\mathrm{dd}$ (doublet of doublet), t (triplet), q (quartet), $\mathrm{m}$ (multiplet). Coupling constants $(\mathcal{J})$ are given in hertz $(\mathrm{Hz})$. Weak or coalesced signals were elucidated by heteronuclear multiple quantum coherence (HMQC) and heteronuclear multiple bond coherence (HMBC) 2D-NMR techniques. Purity of all compounds used in biological assays was $\geq 95 \%$ as measured by Dionex UltiMate 3000 UHPLC+ focused/Thermo Scientific $Q$ Exactive Focus system (Thermo Fisher Scientific, Dreieich, Germany). The system consists of Dionex UltiMate 3000 pump, autosampler, column compartment, diode array detector, and single-quadrupole mass spectrometer, as well as the standard software Xcalibur for operation. RP EC 150/2 NUCLEODUR C18 Pyramid, $3 \mu \mathrm{m}$ (150 mm $\times 2 \mathrm{~mm}$ ) column (Macherey-Nagel, München, Germany) was used as stationary phase, and a binary solvent system $A$ and $B(A=$ water with $0.1 \% F A ; B=M e C N$ with $0.1 \% F A)$ was used as mobile phase. In a gradient run, the percentage of $B$ was increased from an initial concentration of $10 \%$ at $0 \mathrm{~min}$ to $95 \%$ at $5 \mathrm{~min}$ and kept at $95 \%$ for $1.2 \mathrm{~min}$. The injection volume was $2 \mu \mathrm{L}$ and flow rate was set to $500 \mu \mathrm{L} / \mathrm{min}$. MS (ESI) analysis was carried out at a spray voltage of $3800 \mathrm{~V}$, a capillary temperature of $350{ }^{\circ} \mathrm{C}$, and a source CID of $55 \mathrm{~V}$. Spectra were acquired in positive mode from 100 to $1400 \mathrm{~m} / \mathrm{z}$ and at $254 \mathrm{~nm}$ for UV tracing. High-resolution mass spectrometry (HRMS) data was determined by a Thermo Scientific $Q$ Exactive Focus system.

Synthesis and characterization of compounds 2-6 was described before ${ }^{1-3}$.

Synthesis of compound $\mathbf{1}$ started with chloroformylation of 4'-phenoxyacetophenone via Vilsmeier reagent (POCl$/ 3 / \mathrm{DMF})$, followed by a dehydration with hydroxylamine hydrochloride to yield the $\beta$ chlorocinnamonitrile 7 according to a modified Vilsmeier-Haack-Arnold reaction (Scheme S1). Cyclization of 7 with methyl thioglycolate under reflux and basic conditions provided the 3-aminothiophene-2carboxylate 8. In contrast to previous procedures, ${ }^{2}$ the ureido functional group was prepared using mild reagents via a phenyl carbamate intermediate 9.3 Subsequent nucleophilic substitution with $\mathrm{N}$ ethylbenzylamine in DMSO delivered the 3-ureidothiophene-2-carboxylate 10. Saponification of the methyl ester 10 afforded the free acid 1 (Scheme S1). 


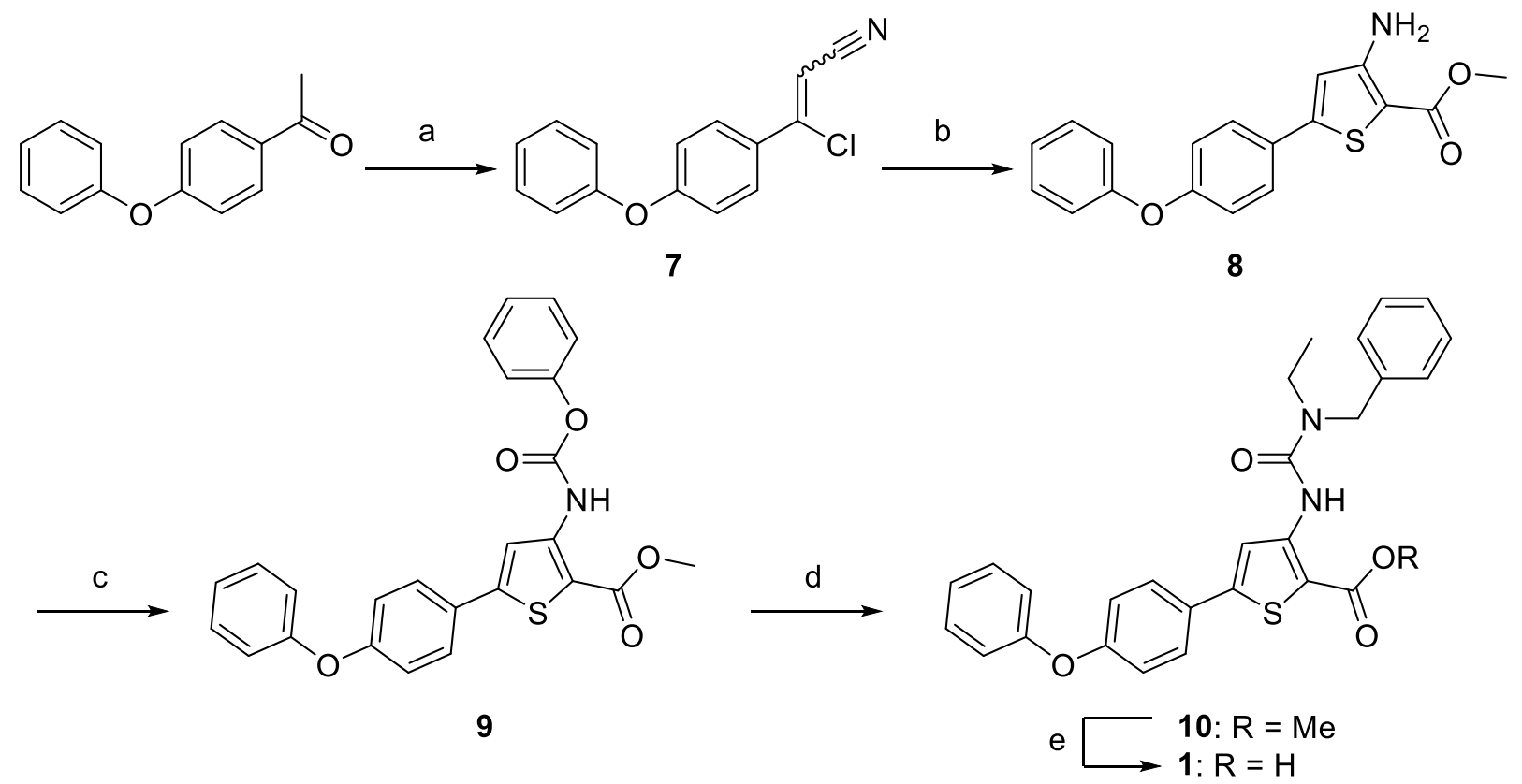

Scheme S1. Synthesis of the 3-ureidothiophene-2-carboxylic acid 1. ${ }^{\mathrm{a}}$

aReagents and conditions: (a) 1) DMF, $\left.\mathrm{POCl}_{3}, 0{ }^{\circ} \mathrm{C}-\mathrm{rt}, 2 \mathrm{~h}, 2\right) \mathrm{NH}_{2} \mathrm{OH} \cdot \mathrm{HCl}$, rt, $16 \mathrm{~h}, 79 \%$; (b) $\mathrm{Na}, \mathrm{MeOH}$, $\mathrm{HSCH}_{2} \mathrm{COOMe}, 70{ }^{\circ} \mathrm{C}, 16 \mathrm{~h}, 66 \%$; (c) CICOOPh, DCM, pyridine, rt, 12 h, 96\%; (d) EtBnNH, DMSO, rt, 2 h, 97\%; (e) $\mathrm{KOH}, \mathrm{MeOH} / \mathrm{THF} / \mathrm{H}_{2} \mathrm{O}, 40{ }^{\circ} \mathrm{C}, 16 \mathrm{~h}, 94 \%$.

\section{3-Chloro-3-(4-phenoxyphenyl)acrylonitrile (7)}<smiles>N#CC=C(Cl)c1ccc(Oc2ccccc2)cc1</smiles>

To a stirred ice-cooled solution of 4'-phenoxyacetophenone (4.25 g, $20 \mathrm{mmol})$ in anhydrous DMF (40 mL, $0.51 \mathrm{~mol}, 25$ equiv), $\mathrm{POCl}_{3}(12.27 \mathrm{~g}, 80 \mathrm{mmol}, 4$ equiv) was added portionwise over 20 min keeping the temperature below $25^{\circ} \mathrm{C}$. The reaction was stirred at $\mathrm{rt}$ for $2 \mathrm{~h}$, then hydroxylamine hydrochloride $(1.53 \mathrm{~g}$, $22 \mathrm{mmol}, 1.1$ equiv) was added cautiously (an exothermic reaction). The reaction was further stirred at rt for $16 \mathrm{~h}$. Water $(200 \mathrm{~mL})$ was added and the mixture was extracted by EtOAc $(3 \times 150 \mathrm{~mL})$. Organic layers were dried $\left(\mathrm{MgSO}_{4}\right)$, filtered, and solvent was removed under reduced pressure. The crude material was sufficiently pure and was used directly for the next step without further purification.

Yield 79\%; yellow liquid. 
Methyl 3-amino-5-(4-phenoxyphenyl)thiophene-2-carboxylate (8)<smiles>COC(=O)c1sc(-c2ccc(Oc3ccccc3)cc2)cc1N</smiles>

To a stirred ice-cooled anhydrous $\mathrm{MeOH}(50 \mathrm{~mL})$ in a $100 \mathrm{~mL}$ two-neck round-bottom flask, sodium metal (483 mg, 21 mmol, 1.4 equiv) was added portionwise under nitrogen atmosphere. After complete dissolution of sodium, methyl thioglycolate $(1.75 \mathrm{~g}, 16.5 \mathrm{mmol}, 1.1$ equiv) was add and the mixture was stirred at $\mathrm{rt}$ for $15 \mathrm{~min}$. $\beta$-Chlorocinnamonitrile $7(3.84,15 \mathrm{mmol})$ was added and the reaction was stirred at $70{ }^{\circ} \mathrm{C}$ under reflux condition for $16 \mathrm{~h}$. Solvent was removed under reduced pressure, water $(100 \mathrm{~mL})$ was added and the mixture was extracted by EtOAc $(2 \times 80 \mathrm{~mL})$. Organic layers were dried $\left(\mathrm{MgSO}_{4}\right)$, filtered, and solvent was removed under reduced pressure. The crude material was dissolved in toluene $(3 \mathrm{~mL})$ and was purified by flash chromatography $\left(\mathrm{SiO}_{2}\right.$, petroleum ether 40/60-EtOAc $\left.=6: 1\right)$.

Yield 66\%; yellowish white solid; ${ }^{1} \mathrm{H}$ NMR $\left(500 \mathrm{MHz}, \mathrm{CDCl}_{3}\right) \delta 7.55$ (d, $J=8.9 \mathrm{~Hz}, 2 \mathrm{H}$ ), 7.38 (dd, $J=8.5$, $7.5 \mathrm{~Hz}, 1 \mathrm{H}$ ), 7.16 (tt, $J=7.5,1.0 \mathrm{~Hz}, 1 \mathrm{H}), 7.06$ (dd, $J=8.5,1.0 \mathrm{~Hz}, 2 \mathrm{H}), 7.01$ (d, $J=8.9 \mathrm{~Hz}, 2 \mathrm{H}), 6.71$ (s, 1H), 5.49 (br s, 2H), 3.85 (s, 3H); ${ }^{13} \mathrm{C}$ NMR (126 MHz, $\left.\mathrm{CDCl}_{3}\right) \delta 164.92,158.28,156.37,154.36,148.61$, 129.89 (2C), 128.21, 127.41 (2C), 123.87, 119.39 (2C), 118.70 (2C), 114.94, 99.87, 51.27; HRMS (ESI+) calcd. for $\mathrm{C}_{18} \mathrm{H}_{16} \mathrm{NO}_{3} \mathrm{~S}[\mathrm{M}+\mathrm{H}]^{+}: 326.0851$, found: 326.0838 .

\section{Methyl 3-[(phenoxycarbonyl)amino]-5-(4-phenoxyphenyl)thiophene-2-carboxylate (9)}

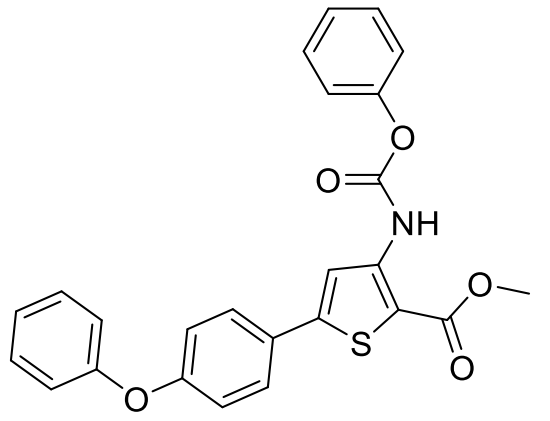

To a stirred ice-cooled solution of the 3-aminothiophene 8 (976 mg, $3 \mathrm{mmol})$ and pyridine $(261 \mathrm{mg}, 3.3$ mmol, 1.1 equiv) in anhydrous DCM (20 mL), phenyl chloroformate (517 mg, $3.3 \mathrm{mmol}, 1.1$ equiv) was added dropwise. The reaction mixture was stirred at $\mathrm{rt}$ for $12 \mathrm{~h}$. Solvent was removed under reduced pressure, and the residue was dissolved in EtOAc $(50 \mathrm{~mL})$. The organic layer was washed with $1 \mathrm{M} \mathrm{HCl}(2$ $\times 25 \mathrm{~mL})$, dried $\left(\mathrm{MgSO}_{4}\right)$, filtered and solvent was removed under reduced pressure. The obtained material was sufficiently pure and was used directly for the next step without further purification.

Yield 96\%; yellow liquid; HRMS (ESI+) calcd. for $\mathrm{C}_{25} \mathrm{H}_{20} \mathrm{NO}_{5} \mathrm{~S}[\mathrm{M}+\mathrm{H}]^{+}:$446.1062, found: 446.1049 . 


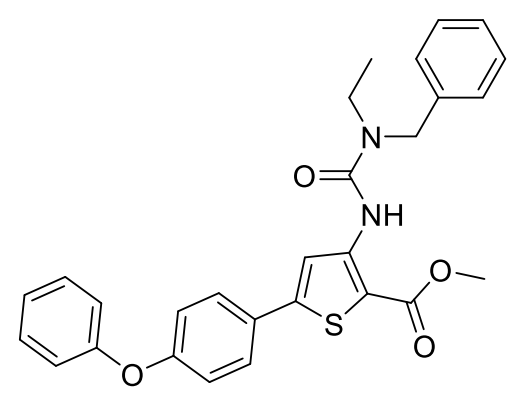

In a $50 \mathrm{~mL}$ two-neck round-bottom flask, the carbamate 9 (312 $\mathrm{mg}, 0.7 \mathrm{mmol})$ was dissolved in anhydrous DMSO (10 mL) under nitrogen atmosphere. $N$-Ethylbenzylamine (101 mg, $0.75 \mathrm{mmol}, 1.07$ equiv) was added dropwise and the reaction mixture was stirred at $\mathrm{rt}$ for $2 \mathrm{~h}$. EtOAc $(50 \mathrm{~mL})$ was added and the organic layer was washed with $1 \mathrm{M} \mathrm{HCl}(2 \times 30 \mathrm{~mL})$, then $1 \mathrm{M} \mathrm{NaOH}(2 \times 30 \mathrm{~mL})$, dried $\left(\mathrm{MgSO}_{4}\right)$, filtered and solvent was removed under reduced pressure. The obtained material was sufficiently pure and was used directly for the next step without further purification.

Yield 97\%; yellow liquid; HRMS (ESI+) calcd. for $\mathrm{C}_{28} \mathrm{H}_{27} \mathrm{~N}_{2} \mathrm{O}_{4} \mathrm{~S}[\mathrm{M}+\mathrm{H}]^{+}:$487.1692, found: 487.1684.

\section{3-(3-Benzyl-3-ethylureido)-5-(4-phenoxyphenyl)thiophene-2-carboxylic acid (1)}

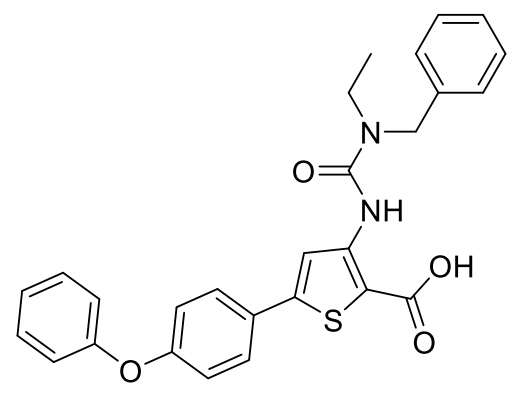

To a stirred solution of the thiophene-2-carboxylic acid methyl ester 10 (341 mg, $0.7 \mathrm{mmol}$ ) in MeOH-THF mixture $(1: 1,20 \mathrm{~mL}), \mathrm{KOH}(118 \mathrm{mg}, 2.1 \mathrm{mmol}, 3$ equiv) in water $(10 \mathrm{~mL})$ was added. The reaction mixture was stirred at $40{ }^{\circ} \mathrm{C}$ for $16 \mathrm{~h}$, then it was concentrated under reduced pressure. The residue was diluted with water $(20 \mathrm{~mL})$, cooled in an ice bath and acidified by $\mathrm{KHSO}_{4}$ (saturated aqueous solution) to $\mathrm{pH} 4-5$. The precipitated solid was extracted by EtOAc $(2 \times 30 \mathrm{~mL})$. Organic layers were dried $\left(\mathrm{MgSO}_{4}\right)$, filtered and solvent was removed under reduced pressure to afford the target compound 1 . The crude material was triturated with petroleum ether $40 / 60(50 \mathrm{~mL})$, stirred in a water bath at $40{ }^{\circ} \mathrm{C}$ for $10 \mathrm{~min}$, cooled, and collected by filtration.

Yield 94\%; off white solid; ${ }^{1} \mathrm{H}$ NMR $\left(500 \mathrm{MHz}\right.$, DMSO- $\left.d_{6}\right) \delta 13.37$ (br s, $\left.1 \mathrm{H}\right), 10.10$ (br s, $\left.1 \mathrm{H}\right), 8.23(\mathrm{~s}, 1 \mathrm{H})$, $7.72(\mathrm{~d}, J=8.7 \mathrm{~Hz}, 2 \mathrm{H}), 7.44$ (t, $J=7.6 \mathrm{~Hz}, 2 \mathrm{H}), 7.35$ (t, $J=7.0 \mathrm{~Hz}, 2 \mathrm{H}), 7.31$ (d, J=7.0 Hz, 2H), 7.27 (t, $J$ $=7.0 \mathrm{~Hz}, 1 \mathrm{H}), 7.20(\mathrm{t}, J=7.6 \mathrm{~Hz}, 1 \mathrm{H}), 7.10(\mathrm{~d}, J=7.6 \mathrm{~Hz}, 2 \mathrm{H}), 7.05(\mathrm{~d}, J=8.7 \mathrm{~Hz}, 2 \mathrm{H}), 4.58(\mathrm{~s}, 2 \mathrm{H}), 3.38$ (q, $J=7.0 \mathrm{~Hz}, 2 \mathrm{H}), 1.15$ (t, $J=7.0 \mathrm{~Hz}, 3 \mathrm{H}) ;{ }^{13} \mathrm{C}$ NMR $(126 \mathrm{MHz}$, DMSO-d6) $\delta$ 165.83, 158.00, 155.79, 153.08, 147.26, 146.95, 138.17, 130.29 (2C), 128.56 (2C), 127.71, 127.66 (2C), 127.19 (3C), 124.25, 119.47 (2C), $118.74(2 \mathrm{C}), 116.82,106.27,49.33,41.83,13.19$; HRMS (ESI+) calcd. for $\mathrm{C}_{27} \mathrm{H}_{25} \mathrm{~N}_{2} \mathrm{O}_{4} \mathrm{~S}[\mathrm{M}+$ $\mathrm{H}^{+}$: 473.1535, found: 473.1522 . 


\section{UHPLC-HRMS, ${ }^{1} \mathrm{H}$ - and ${ }^{13} \mathrm{C}$-NMR Spectra of the Described Compounds}

\section{Compound 8}

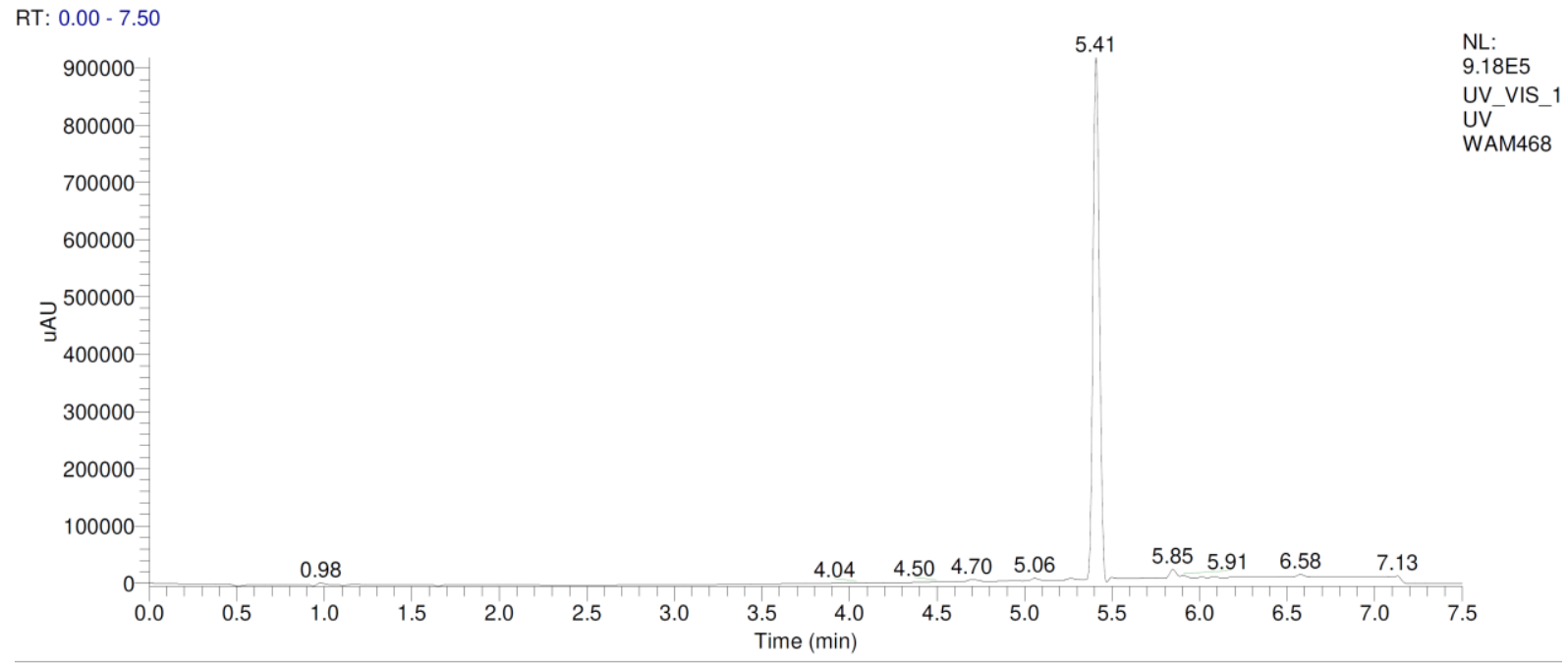

WAM468 \#1207-1212 RT: 5.40-5.42 AV: 6 NL: 4.44E9

T: FTMS + p ESI Full ms [120.0000-1400.0000]

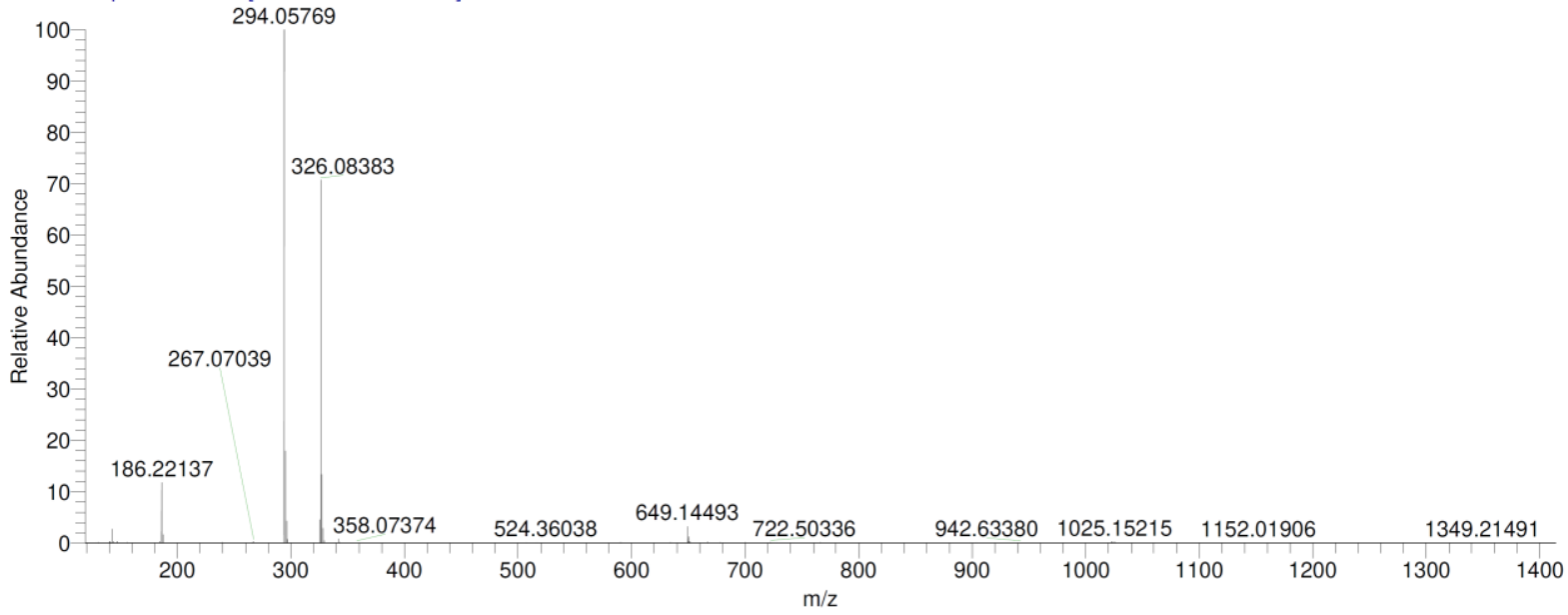



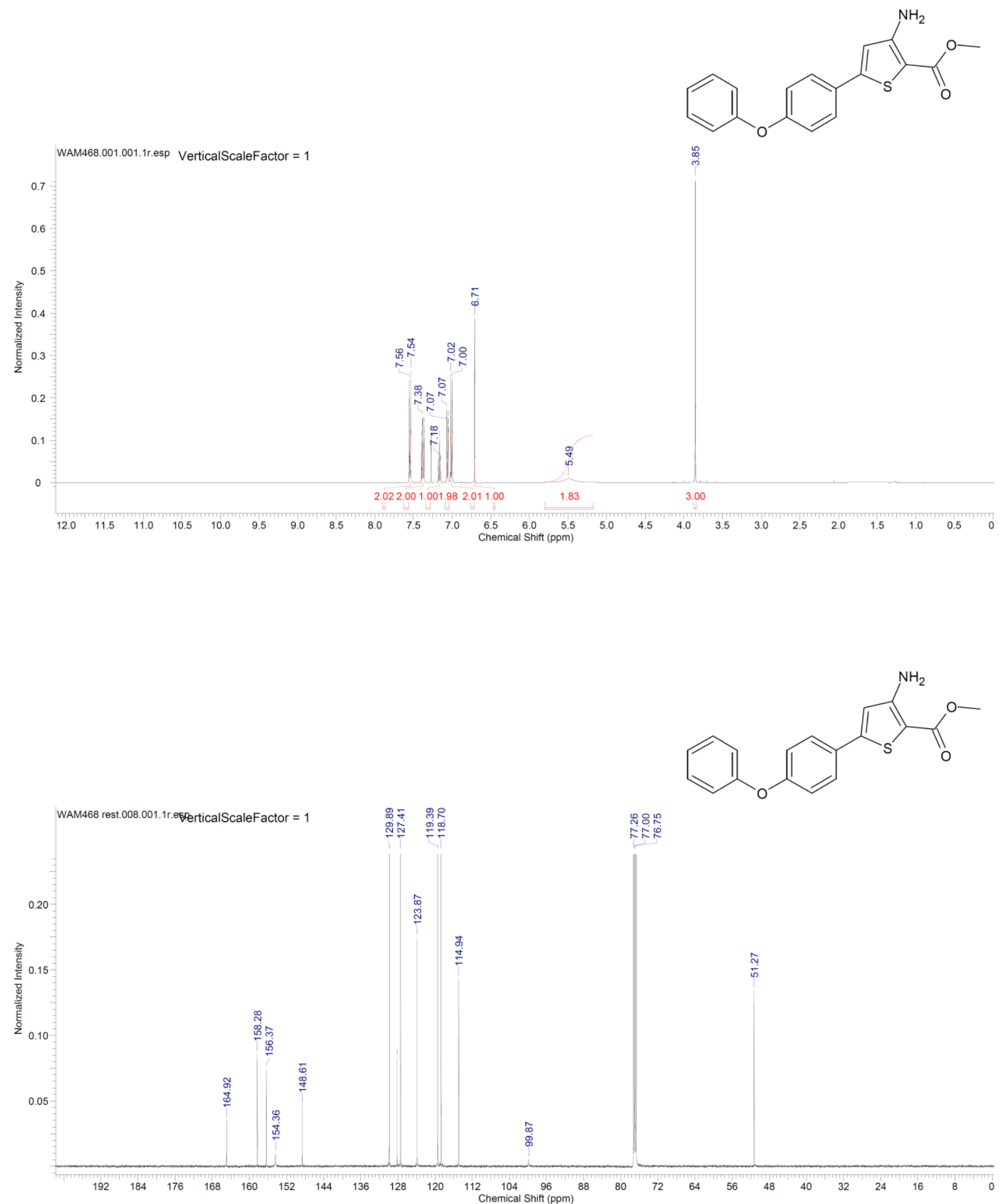


\section{Compound 9}

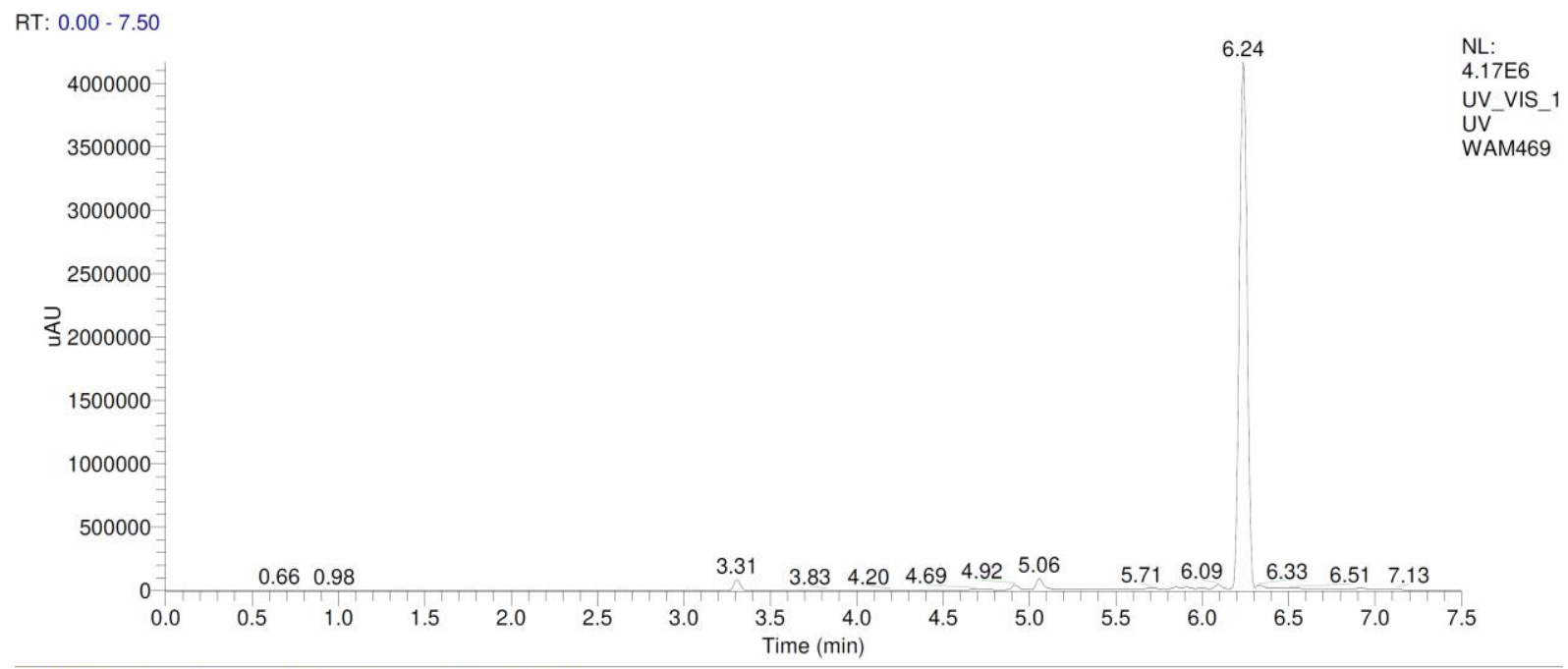

WAM469 \#1394-1399 RT: 6.24-6.26 AV: 6 NL: 3.58E7

T: FTMS + p ESI Full ms [120.0000-1400.0000]

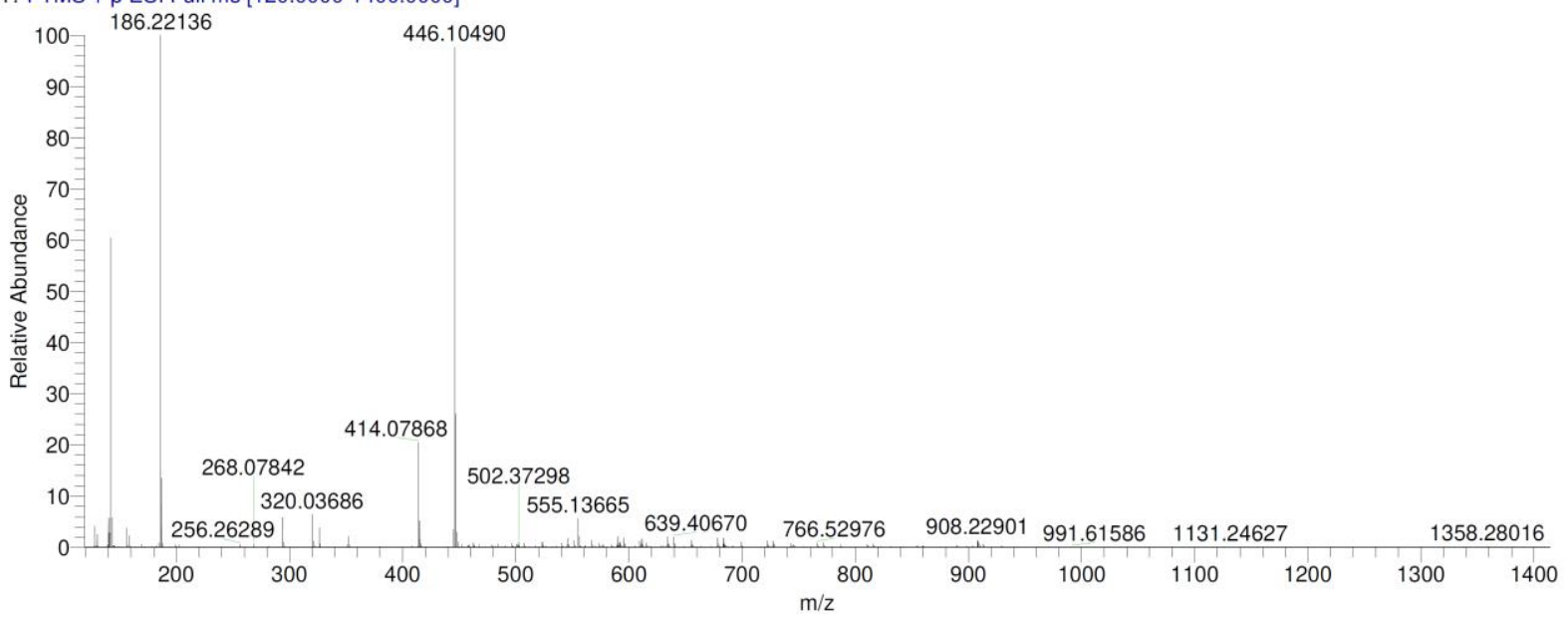




\section{Compound 10}

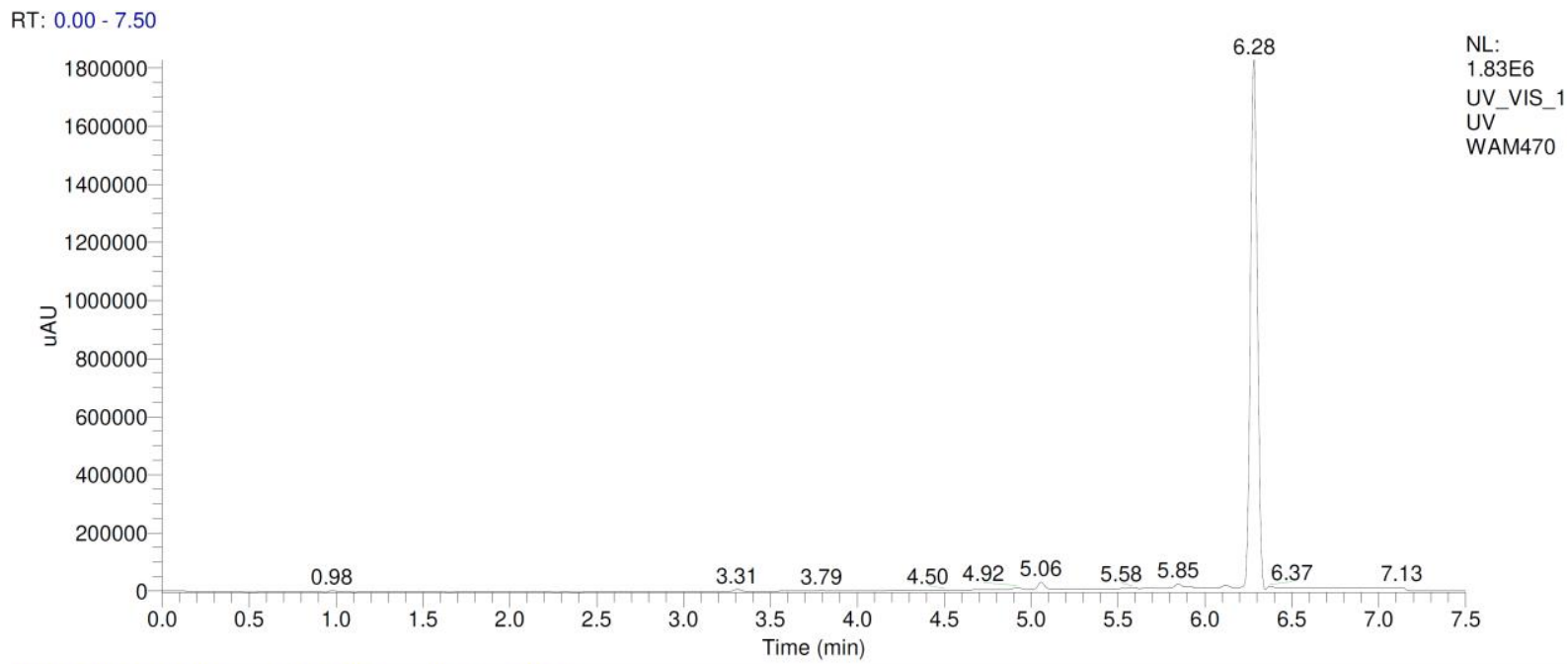

WAM470 \#1401-1408 RT: 6.27-6.30 AV: 8 NL: 3.09E8

T: FTMS + p ESI Full ms [120.0000-1400.0000]

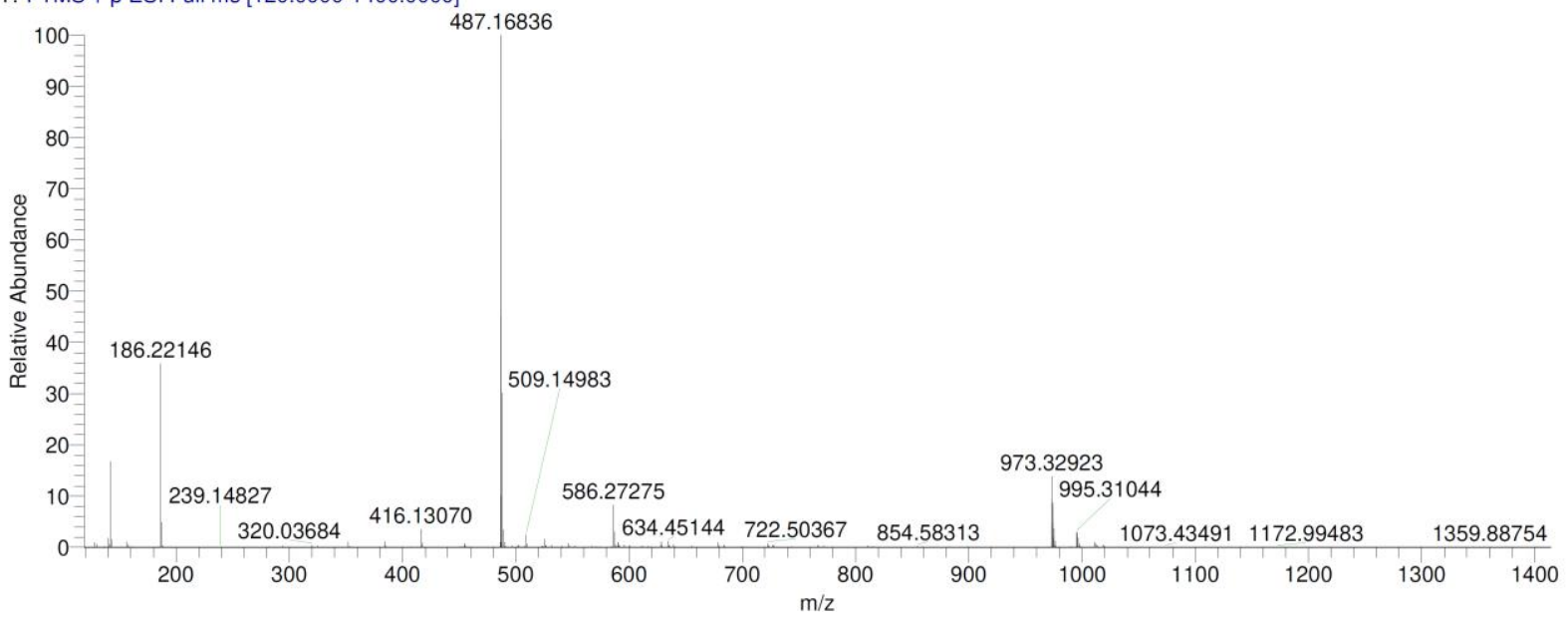




\section{Compound 1}

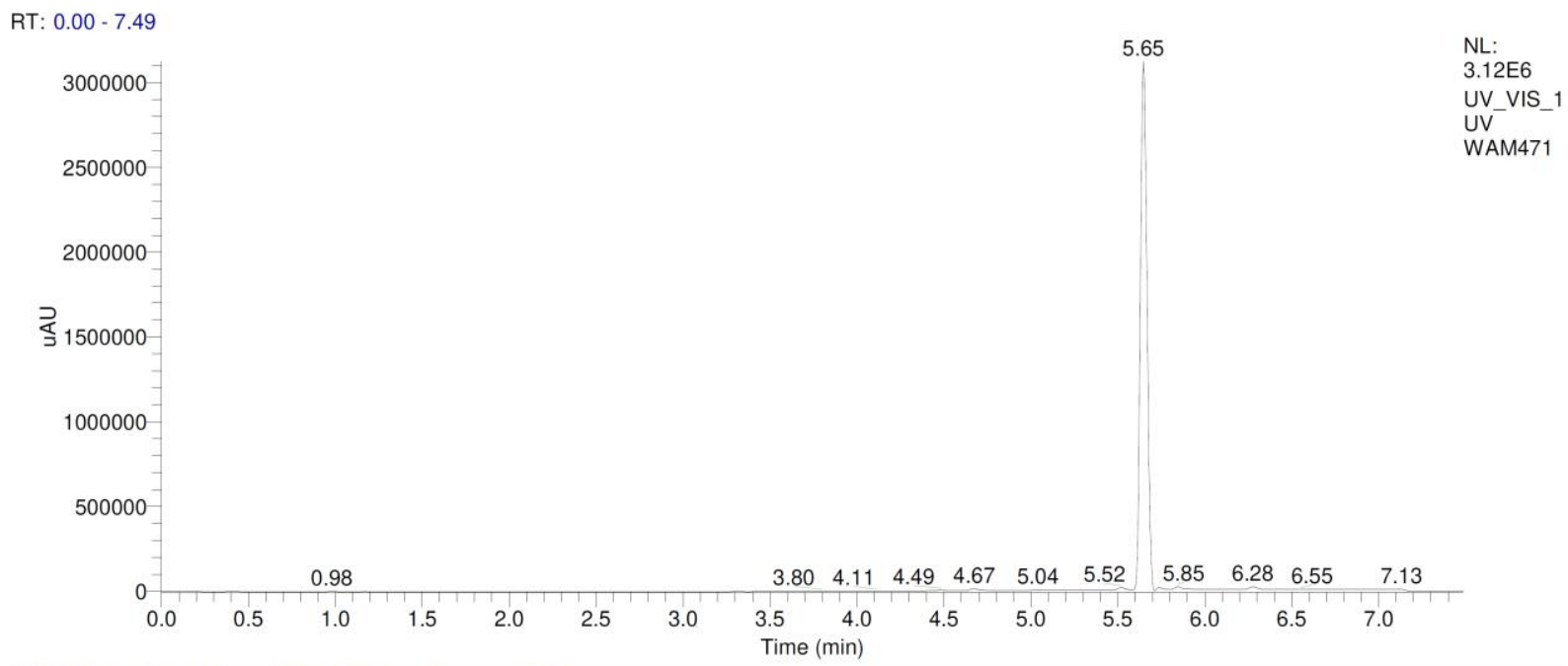

WAM471 \#1261-1266 RT: 5.65-5.67 AV: 6 NL: 4.73E8

T: FTMS + p ESI Full ms [120.0000-1400.0000]

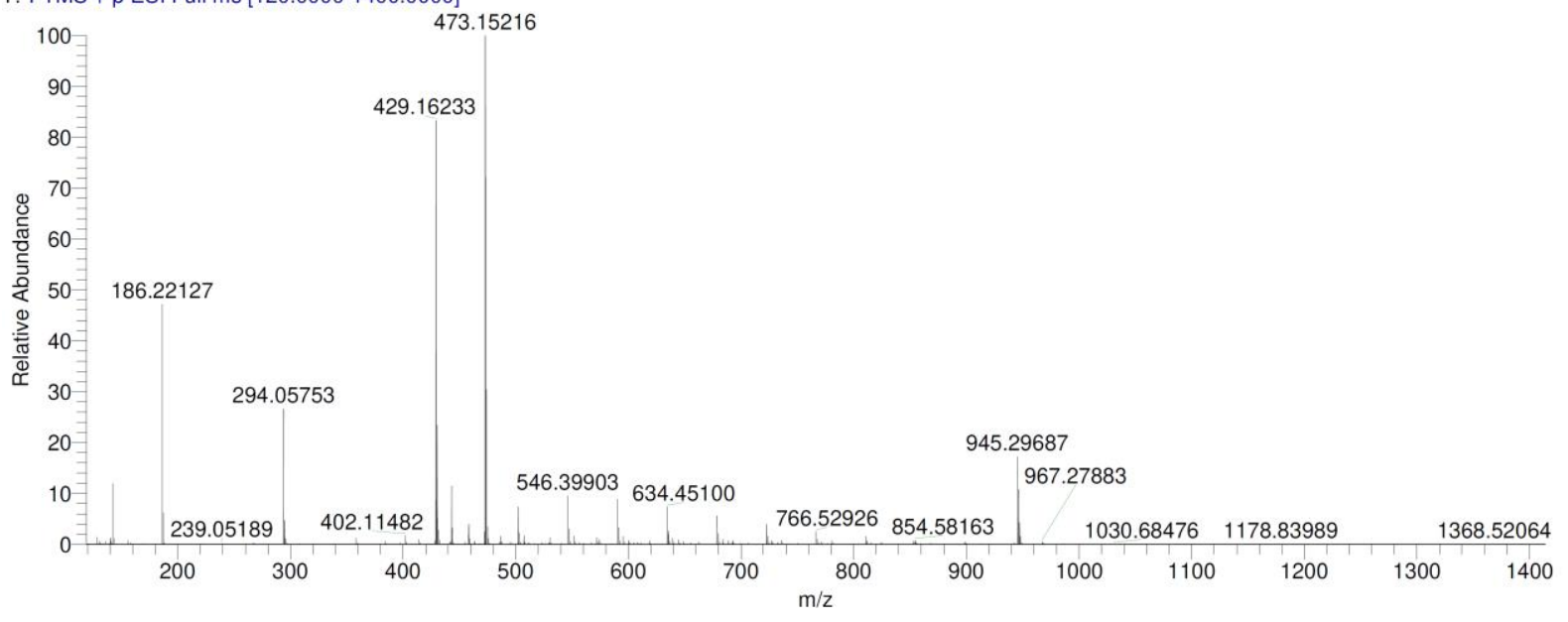



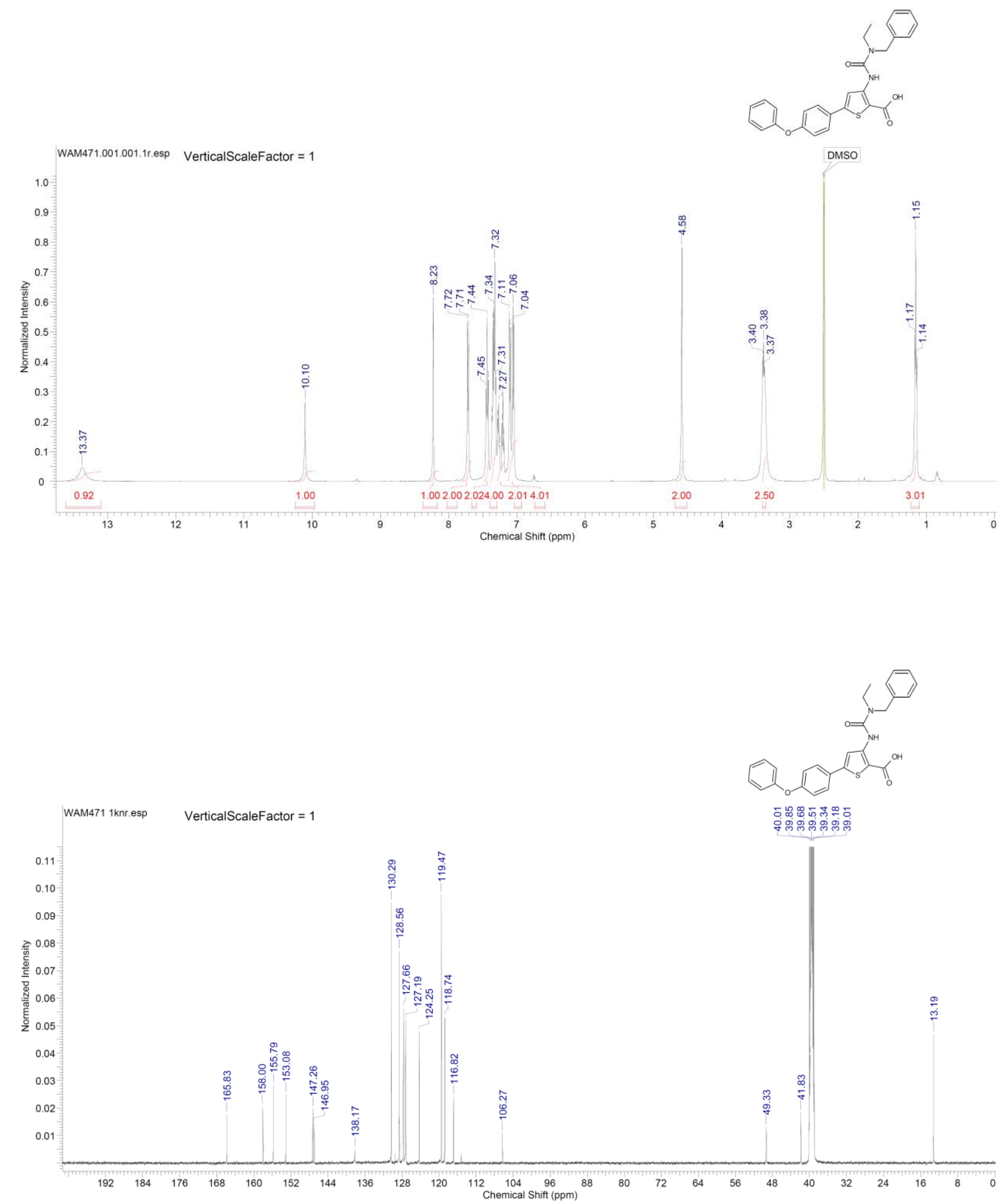


\section{References}

(1) Sahner, J. H., Groh, M., Negri, M., Haupenthal, J., and Hartmann, R. W. (2013) Novel small molecule inhibitors targeting the "switch region" of bacterial RNAP. Structure-based optimization of a virtual screening hit, Eur J Med Chem 65, 223-231. DOI: 10.1016/j.ejmech.2013.04.060.

(2) Elgaher, W. A. M., Fruth, M., Groh, M., Haupenthal, J., and Hartmann, R. W. (2014) Expanding the scaffold for bacterial RNA polymerase inhibitors. Design, synthesis and structure-activity relationships of ureido-heterocyclic-carboxylic acids, RSC Adv 4, 2177-2194. DOI: 10.1039/C3RA45820B.

(3) Elgaher, W. A. M., Sharma, K. K., Haupenthal, J., Saladini, F., Pires, M., Real, E., Mely, Y., and Hartmann, R. W. (2016) Discovery and Structure-Based Optimization of 2-Ureidothiophene-3-carboxylic Acids as Dual Bacterial RNA Polymerase and Viral Reverse Transcriptase Inhibitors, J Med Chem 59, 7212-7222. DOI: 10.1021/acs.jmedchem.6b00730. 